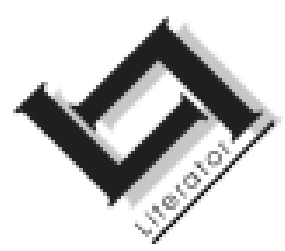

\title{
Die gesprek tussen C.M. van den Heever se werk en enkele moderne Suid-Afrikaanse romans
}

\author{
H.P. van Coller \\ Departement Afrikaans en Nederlands, Frans en Duits \\ Universiteit van die Vrystaat \\ BLOEMFONTEIN \\ E-pos: fgvc.rd@mail.uovs.ac.za
}

\section{Abstract}

The discourse between Van den Heever's work and a few modern Afrikaans novels

Many contemporary critics have castigated Van den Heever for what they allege is his dichotomy between realism and romanticism. But as J.M. Coetzee has indicated, there is in fact no dichotomy: Van den Heever's portrayal of reality leads quite naturally to its interpretation.

This article assumes that Van den Heever's works were rooted firmly in reality and were in effect early examples of littérature engagée. His approach has much to do with the seminal nature of his farm novels and explains the many intertextual allusions to them in modern Afrikaans novels.

\section{Opsomming}

Die gesprek fussen C.M. van den Heever se werk en enkele moderne Suid-Afrikaanse romans

Baie hedendaagse kritici het Van den Heever gekasty vir wat hulle beskou as ' $n$ dichotomie tussen realisme en romantiek in sy werk. Soos J.M. Coetzee egter aangedui het, is daar in werklikheid geen dichotomie nie: Van den Heever se uitbeelding van die realiteit lei op 'n heel natuurlike wyse tot die interpretasie daarvan.

Hierdie artikel gaan van die standpunt uit dat Van den Heever se werke in die realiteit gegrond was en in werklikheid vroeë voorbeelde van littérature engagée was. Hierdie benadering het heelwat te make met die seminale aard van sy plaasromans en verklaar die groot hoeveelheid intertekstuele toespelings daarop in moderne Afrikaanse romans. 


\section{Inleidende opmerkings: C.M. van den Heever se plek in die Afrikaanse letterkunde}

Raadpleeg 'n mens 'n eietydse literatuurgeskiedenis is dit duidelik dat die werk van C.M van den Heever byna net om literêr-historiese redes waardeer word. Sy plek in die kanon berus op enkele "bevredigende" kortverhale, 'n handjievol gedigte, die novelle Somer en die roman Laat vrugte (kyk Kannemeyer, 1978:310; Du Plooy, 1999:662-663).

Daar is egter ander Afrikaanse literatore wat Van den Heever se werk hoër ag vanweë die plek wat dit inneem binne 'n hele literatuursisteem. Van Coller (1987:41) beweer dat Laat vrugte, geoordeel aan die tradisionele strukturele kriteria, 'n knap roman is. "Wanneer dit egter gesien word binne die genre van die plaasroman en ook binne die Afrikaanse letterkunde (o.a. vanweë sy intertekstuele plek) dan blyk sonder meer dat Laat vrugte een van die sentrale romans in Afrikaans is" (oorspronklike kursivering). In haar latere oorsig van die werk van Van den Heever, maak Heilna du Plooy (1999:663) 'n paar geldige opmerkings. Volgens haar is sy prosatekste nog nie diepgaande genoeg ondersoek as tydsdokumente waarin interessante sosiologiese, ideologiese en religieuse inligting vervat is nie. Verder stel sy dat sy werk ' $n$ belangrike rol gespeel het in die ontwikkeling van die literatuur wat daarop gevolg het.

\section{Van den Heever en die sogenaamde dualiteit: realisme en romantiek}

In eietydse oorsigte van die werk van Van den Heever (kyk Du Buson, 1959:101 e.v.; Haarhoff, 1959:27 e.v.; Malherbe, 1957:15; Schoonees, 1959:84 en Van Heerden, 1959:58.), maar ook in latere beskouings (kyk Kannemeyer, 1978:298, 307 en Du Plooy, 1999:655) is daar 'n hele paar gemene delers. Kritici maak voortdurend gewag van Van den Heever se donker en pessimistiese lewensiening waarin die memento mori, die doodsbesef sentraal staan, van sy metafisiese ingesteldheid en van sy romantiese instelling. In sy werk word die mens geteken as 'n blote stippel teen die uitspansel, gering in sy konflik met kosmiese magte; onderworpe aan die groot gang van die natuur. In Laat vrugte word hierdie stryd van oom Sybrand bykans vergelykbaar met 'n Griekse tragedie.

Kritici (kyk Dekker, 1933; Du Plooy; 1999; Pienaar, 1933 en Van Heerden, 1982) het Van den Heever deurgaans gekritiseer oor sy "vertelafstand". Van den Heever se introspeksies versteur volgens die kritici dikwels die verhaalgang, omdat dit 'n vorm van vertellersmymering 
is. Daarom is sy karakters nie altyd oortuigend nie en raak hulle soms spreekbuise van die verteller/outeur.

Al die bogenoemde besware wek die gevoel dat Van den Heever se werk sig enersyds onttrek aan die werklikheid en andersyds "werklikheidselemente" bloot in diens stel van simboliek, romantiek, of wat dikwels genoem word die oorheersende idee in sy werk. Hierdie besware word dikwels verwoord as die vermeende tweeslagtigheid tussen realisme en romantiek wat soos 'n refrein voorkom by kritici (kyk Antonissen, s.d.:221-227; Du Plooy, 1999:661; Kannemeyer, 1978:298 en Van Heerden, 1982:335-339). Du Plooy (1999:662) beskou baie van hierdie besware as tydsgebonde en vra tereg waarom realisme en romantiek dan nie vermeng mag word nie.

\section{Van den Heever en die aktualiteit}

Wanneer Van den Heever se lewensloop beskou word, blyk dat die agrariese aspek sentraal gestaan het. Nie net het hy grootgeword op die Vrystaatse platteland nie; in 1940 koop hy vir hom 'n stukkie grond aan die Vaalrivier naby Parys en word dit vir hom 'n toevlugsoord waar hy kan ontsnap van die stad "en sy komplekse werklikheid" (Solz, 1959:49). Hoewel hy die grootste gedeelte van sy hele lewe in stede moes deurbring, was hy "nooit van die stad nie" (Haarhoff, 1959:24). In baie van sy werke (soos Op die plaas, Langs die grootpad, Droogte, Groei en in Somer) word stad en platteland teenoor mekaar gestel en aanvanklik is die gevoel dat die stad niks goeds te bied het nie.1

J.M. Coetzee (1988) plaas Van den Heever se romans binne die maatskaplike situasie waarbinne dit ontstaan het en wys op die ideologiese onderbou van Van den Heever se plaasromans. In die tradisionele Afrikaanse plaasroman word die plaas nie net 'n ruimte waarbinne die karakters toevallig leef nie. Die plaas word geteken as 'n mitiese ruimte en die verband tussen boer en kosmos is nie bloot 'n romantiese identifikasie nie; in die prototipiese plaasroman is daar 'n beweging na die openbaring van die plaas as bron van betekenis. Deur die plaas word die Afrikaner geheg aan die aarde en sy geskiedenis, kan hy as 't ware sy aanspraak op die land bevestig. Daarom mag die plaas nooit verlore gaan nie, moet erfopvolging bestendig word, is die plaas in alle opsigte oppermagtig aan die stad. Vir Coetzee bestaan daar nie werklik 'n dualiteit tussen realisme en romantiek in Van den Heever se werk nie: die ervaring van die realiteit gee aanleiding tot die interpretasie daarvan.

$1 \quad$ Ampie Coetzee (2000:85) skryf dat die plaasnarratief ontstaan het vanuit verlies: "die dreigende verlies van die plaas deur natuur, die ekonomie, industrialisasie." 
Du Plooy (1999:655) beweer dat Van den Heever die omstandighede van die individu ontgin binne die raamwerk van 'n bepaalde historiese periode.

Daarom sien 'n mens in sy werk die Afrikaner in sy landelike lewe, sy armoede, sy stryd teen die elemente, in sy soeke na identiteit, die latere verstedeliking van die Afrikaners en die verarming op geestelike en materiële vlak.

So 'n kensketsing van sy oeuvre dui reeds op die strewe na aktualiteit en betrokkenheid in sy werk, 'n opvallende aspek trouens van die hele Afrikaanse prosatradisie; littérature engagée is waarskynlik een van die standhoudendste elemente van die Afrikaanse literatuur.

Word Van den Heever se werk op die voet gevolg, is dit duidelik dat dit inderdaad enersyds die geskiedenis van die Afrikaner in die eerste helfte van die twintigste eeu karteer; andersyds op 'n persoonlike wyse Van den Heever se eie (ontwikkelende) sienings van aktuele probleme weergee: onder meer arbeidsverhoudings, ekonomiese emansipasie, huweliksverhoudings en -ontwrigting, die sosiale posisie van die vrou en vroueregte, en selfverwesenliking teen die heersende moraal. Hierdie aktualiteitsaspek van sy werk impliseer uiteraard 'n positiewe waardeoordeel.

Dit is dikwels die geval dat die essensiële of tipiese kenmerke van 'n beweging, periode en ook 'n oeuvre die duidelikste (nie die beste nie!) tot uitdrukking kom in swakker, selfs marginale werke. Hier kan gedink word aan die tipiese Dertigertematiek in verse in die debuutbundel van W.E.G. Louw; die handgrepe van Sestig in die epigone-poësie van Pieter Venter of in die roman Want ons is van gister (Kobus van Zyl) en kenmerke van grensliteratuur in Riana Scheepers se werk, Die heidendogters jubel. Een van Van den Heever se minder suksesvolle werke is seker die roman Groei (1933). Dit is volgens Kannemeyer (1978:303) die eerste keer dat die stad as tema 'n prominente plek inneem binne die Afrikaanse roman. Volgens hom word die stadslewe te oppervlakkig, eensydig en karikaturaal gesien. In hierdie opsig stem dit eintlik ooreen met sy latere werk, soos Vannag kom die ryp (1952) en Dirk se oorwinning (1952). Tog is veral Groei 'n staalkaart van "plattelandsveraming en plaasverlating".

Lees ons hierdie roman egter binne sy historiese tydsgewrig, staan die aktualiteit skerper uit. Veral ná die Anglo-Boereoorlog het die Afrikaner geworstel om ekonomies te oorlewe op hul plase en 'n proses van verstedeliking het noodwendig gevolg. Só het daar 'n duidelike onderskeibare groep ontstaan, die sogenaamde "armblankes". In 1927 
bring die president en die sekretaris van die Carnegie-korporasie 'n besoek aan Suid-Afrika. Na 'n versoek van die Nederduitse Gereformeerde Kerk, stem die Carnegie-Korporasie in om 'n ondersoek na die armblankevraagstuk geldelik te ondersteun. Die verslag, wat uit ses dele bestaan, word in 1932 gepubliseer.

In die verslag van die Carnegie-ondersoek word "armblankes" bestempel as "persone van Europese afstamming wat hoofsaaklik uit die boerdery hulle bestaan gemaak het of nog maak" (Grosskopf, 1932: e.v.). Die belangrikste groepe is "arm bywoners, huurlinge op plase, eienaars van stukkies aandele van 'n plaas waarmee geen bestaan gemaak kan word nie, arm nedersetters, en die toenemende groep van ongeskoolde of swak geskoolde werkers en arbeiders buitekant die boerdery".

Van den Heever skryf gewoonlik oor die Vrystaatse plaaslewe, dit wat hy in sy jeug geken het. Uit die Carnegie-verslag blyk dat die Vrystaat (met $29,3 \%$ ) die grootste persentasie van hul boorlinge aan ander provinsies afgestaan het; derhalwe gedeeltelik ook aan stedelike gebiede. In die Vrystaat word ook van die grootste reënarm gebiede aangetref én is die verhouding van landelike tot stedelike bevolking ook van die hoogste, "sowel as [saam met die Kaapprovinsie] die hoogste percentasie van manlike neringdoendes in die landbouberoepe" (Grosskopf, 1932:1-61). Hieruit blyk al dat Van den Heever se romans met hul beskrywing van plaasverlating, armoede en droogte, swak finansiële insig (Somer en Kromburg), bywoners en huurarbeiders (soos Wynand in Somer) geanker is in die aktualiteit van sy tyd.

In die verslag word breedvoerig ingegaan op die redes vir die verarming van die boerebevolking; redes wat as motiewe bykans almal voorkom in Van den Heever se werk: die Anglo-Boereoorlog, versnipperde en onderverdeelde grondbesit wat aanleiding gegee het tot onekonomiese boerdery-eenhede (veral in reënarm gebiede), swak vergoeding aan arbeiders of bywoners, onkundigheid oor moderne geldhandel (hulle het as onkundiges dikwels aan die kortste end getrek "in die stryd teen die handelaar, die spekulateur, die 'agent'”, Grosskopf, 1932:1-111), die toename van 'n boerebevolking sonder eie grond gepaardgaande met duur huurpryse en 'n hele reeks ander faktore (soos droogte) wat die verarmde boerebevolking verhinder het om hul toestand én hulself te verbeter.

Dit spreek daarom vanself dat Van den Heever se implisiete waarskuwing teen verstedeliking in Groei waarskynlik veral die moedeloses geld wat dit nie langer op die platteland kon uithou nie. In hierdie roman word mense gewaarsku teen die trek na die stad waar geen werk is nie, op die "onvoldaanheid wat die 'vrye' lewe by die niksdoende mense soos 
mev. Van Straaten skep" (Pienaar, 1959:181), op die inpak wat verstedeliking het op 'n gelukkige huwelik, op kulturele vervlakking van die nouveau riche.

In die Carnegie-verslag word nogal skerp uitgevaar teen hulle wat verkondig: "Die armes moet op die plase gehou word. Hulle moet uit die stede en dorpe geweer word" (Grosskopf, 1932:1-76). As hulle op die plase sou bly, sou hul ellende dalk nie so sigbaar gewees het nie, "(m)aar die gemiddelde welvaart van die blanke bevolking sou daardeur nie gunstiger staan en die landelike armoede daardeur nie verdwyn nie". Reeds in 1899 is "burgerregerwe" toegeken in dorpe en stede en daardeur is verstedeliking gestimuleer én gepaardgaande daarmee ook die armoede omdat baie van die bewoners arm was. Die slotsom van dié gedeelte van die verslag is dat mense wat op die platteland groot geword het, nie maklik na die stad verhuis nie: "die meeste trek omdat die boerdery vir hulle nie 'n bestaanbare lewe verseker nie". Hoe moet Van den Heever se duidelike voorkeur vir bly op, of terugkeer na die plaas in die lig hiervan begryp word?

\section{Van den Heever die romantikus}

In Groei het ons Van den Heever die idealis aan die woord. Eers teken hy die stad met sy leegheid en oppervlakkigheid. Daarna die terugkeer na die platteland wat die redding bring. Dit is asof Van den Heever suggereer dat dit beter is om op die plaas te bly ten spyte van natuurrampe en armoede, "maar hy laat die ou vader weer met profetiese leiding ons wys op die weg wat ons voorvadere betree het, 'n lydensweg van baie offers en trane, maar dis alleen deur die swaarkry wat die innerlike verdieping en sielsreiniging kom, en die nuwe vertroue gebore word" (Pienaar, 1959:180).

Maar miskien is dit korrekter om te sê dat dit Van den Heever die romantikus is wat hier praat. 2 In haar "herbesoek" aan die romantiese prosa in Afrikaans maak Elize Botha (1983:2) gewag van die twee bevrugtende bronne van die romantiek: die vryheidgedagte en die gevoelslewe. Maar inherent aan die romantiek is ook die nasionalisme, en gepaardgaande daarmee 'n nuwe belangstelling in die volksverlede

$2 \quad$ By die romantikus gaan dit om die realisme in diens van ' $n$ bepaalde lewenshouding. In wese staan dit eintlik nie so ver van byvoorbeeld ' $n$ bepaalde variant van die realisme, naamlik die sosialistiese-realisme nie. Daar staan die realisme ook in diens van " $n$ bepaalde ideologie. Die weergawe van die werklikheid "soos dit is" is " $n$ illusie. Grové (1951:10) verwyt plaasromanskrywers soos Van Bruggen, Malherbe en Van den Heever dat hul almal die werklikheid ontvlug; dus die tradisionele realisme én romantici. 
(sy tradisies, verhale, mites, objekte), bykans 'n nostalgiese in-herinnering-roep van dit wat was (Pereira, 1992:448; Van Gorp e.a., 1998: 389).

Dit is opvallend hoe hierdie drie aspekte deurgaans voorkom in Van den Heever (en Malherbe) se werk. Miskien vind hulle juis 'n knoopplek in die plaas as ruimte: dit is 'n ruimte waar die enkeling op onafhanklike en heroïese wyse die stryd kan opneem teen die kosmiese magte (en alle konflikterende persone en ruimtes daarbuite), waar arbeid 'n etiese dimensie verkry omdat die plaas se voortbestaan daardeur verseker word. Só word skuld betaal aan die voorgeslagte en verpligtinge aan die nageslagte nagekom. Van den Heever (en Malherbe) se soms minutieuse beskrywings van plaasarbeid, hul weergawes van gebruike en gewoontes; die optekening van karakteriserende taalgebruik ${ }^{3}$ én die lang introspeksies kom alles voort uit 'n romantiese (en in wese nasionalistiese) lewenshouding en maak die opmerkings oor 'n realistiese en romantiese dualiteit eintlik niksseggend. 4

\section{Van den Heever se plaasromans: resonansie in, en gesprek met enkele Afrikaanse plaasromans}

In Van Coller (1987) en Van Coller (1995) is reeds uitvoerig verwys na die seminale plek van Laat vrugte binne die tradisie van die Afrikaanse plaasroman en die Afrikaanse letterkunde. Daar is ook kortliks gefokus op die interteksuele verband tussen hierdie roman en (post-) moderne Afrikaanse plaasromans van onder andere André P. Brink, Etienne Leroux, Karel Schoeman, Etienne van Heerden en Eben Venter (Van Coller, 1995:26 e.v.). Ander moderne Afrikaanse plaasromans kan ook direk in verband gebring word met Van den Heever se Laat vrugte. Anna M. Louw se Kroniek van Perdepoort kan vrugbaar vergelyk word, veral ten aansien van die fatumgelaaide gegewe en uitbeelding van die hoofpersoon. Uitdraai (1976) van Wilma Stockenström beskrywe ook 'n verbode, buite-egtelike verhouding, maar verbreek nie net die ras-taboe

3 In Die meulenaar word die leser verplaas na die einde van die negentiende eeu; in Laat vrugte na die eerste twee dekades van die twintigste eeu. Albei boeke is derhalwe reeds weergawe van die verlede en ten spyte van kritiek, tog 'n bejubeling van die pioniersverlede. Pereira (1992:451) skryf: "[Die romantici se] belangstelling in ' $n$ klassieke kennis en kultuur stry hoegenaamd nie teen hul verwerping van neoklassieke waardes nie: dit was die gees van die verlede wat hulle wou laat herleef."

Elize Botha (1983) lees C.M. van den Heever se roman Kromburg (1937) as "'n stofbewerking wat onweerlegbaar stam uit die romantiek - 'n stelling waarmee ek bewustelik ingaan teen die standaardopvattings van bv. Antonissen en Kannemeyer dat Kromburg in die realistiese tradisie gesien moet word" (Antonissen, 1965:224, 225; Kannemeyer, 1978:304). 
nie, maar ondersoek (en herdefinieer) die rol van die onafhanklike en ambisieuse vrou, op die spoor van Malherbe se Die meulenaar en Van den Heever se Kromburg.

Die motiewe van erfopvolging, dominerende patriarge en ruimtelike determinisme bring Alexander Strachan se Die jakkalsjagter (1990), Etienne van Heerden se Die stoetmeester (1993) en Hierdie lewe (1993) almal direk in verband met Laat vrugte, terwyl die laasgenoemde roman van Karel Schoeman ook die motief van die periferale rol van die vrou (hier weer die dienende Marta, maar tewens ook ambisieuse vrou) ondersoek. In Kikoejoe (1996) kom die persiflage oor 'n hele spektrum voor: die argetipiese heroïese boerepatriarg is nou 'n daadlose, geestesieke, en die moeder lyk meer na die "volksvreemde" Maggie uit Laat vrugte as op die pioniersvrou, tant Willa of die dienende Marta, tant Betta. ${ }^{5}$ Dit is egter veral die ruimte wat gedekonstrueer word: die Afrikaner-erfplaas met sy streng hiëragie word nou 'n vakansieplaas waar 'n hele reeks vreemde en verloopte karakters naas mekaar lewe. In 'n sekere opsig herinner dit weer aan Schoeman se apokaliptiese roman, $\mathrm{Na}$ die geliefde land (1972), waar die erfplaas in die herinneringe van George slegs figureer as "vakansieruimte" (Koch, 2002:328). In sekere opsigte - soos die onderliggende apokaliptiese visie - is hierdie vroeë roman van Schoeman ook die radikaalse afrekening met die plaasroman (kyk ook Koch, 2002:262-371).

\section{Van den Heever se plaasromans: resonansie in, en gesprek met ander (Suid-) Afrikaanse romans}

In pas met my vroeëre opmerkings, is ek van mening dat die krag van 'n paradigma, 'n periode, literêre sisteem of kanon bepaal kan word deur te kyk na aangrensende gekodifiseerde sisteme. Overgeset synde: die werklike invloed van 'n subgenre (en 'n seminale teks binne so 'n subgenre) kan soms afgelei word uit 'n ondersoek van aangrensende subgenres. So is die tipiese patrone van Laat vrugte (die dominerende vaderfiguur, die onderdrukte moeder, die ongeoorloofde liefdesverhouding, die buite-egtelike kind, vyandskap met die bure, die uiteindelike vredemaak en inkeer) al deur opeenvolgende studentegroepe in my prosakursusse opgespoor en aangetoon in tientalle ontspanningsromans in Afrikaans. Vervolgens wil ek graag die aandag verskuif na enkele tekste wat die afgelope jare in Suid-Afrika die lig gesien het. Hoewel

5 In haar karakterisering toon sy opvallende ooreenkomste met die fokalisator, Gertie se moeder in Jeanne Goosen se novelle Ons is nie almal so nie (1990), wat reeds ' $\mathrm{n}$ ideologiese herskrywing was van die "tipiese" Afrikanervrou-tipe. 
hulle weliswaar slegs marginaal skakel met die Afrikaanse plaasroman as subgenre, is hul almal seminale tekste. Boonop behoort hul almal tot verskillende soort literatuur, bykans subgenres. Triomf (1993) deur Marlene van Niekerk vind as voorstadroman aansluiting by 'n hele tradisie in die Afrikaanse letterkunde. Ek stamel ek sterwe (1996) deur Eben Venter hoort tot 'n beduidende groep tekste wat goedskiks as "diaspora-literatuur" bestempel sou kon word, terwyl Disgrace (2000) deur J.M. Coetzee tuishoort by "post-apartheid"- of apokaliptiese literatuur.

Miskien verdien die voorafgaande indeling verdere opheldering. Voorstadliteratuur (waaronder ook Tom Dreyer se Stinkafrikaners, Erika Murray-Theron se Sê Maria, Francois Loots se Nagvoëls en dalk selfs Harry Kalmer se Kniediep), speel af op die rand van 'n stad en hierdie tussenruimte (tussen platteland en stad) staan sentraal in die storie, die lotgevalle van karakters, die wyse van karakterisering en die onderliggende werklikheidsiening of ideologie. Diasporaliteratuur is literatuur deur (en/of oor) Afrikaners in die vreemde: Breyten Breytenbach se Woordwerk, Eben Venter se My simpatie, Rina Sherman se Uitvlug en talle ander tekste deur Louis Kruger, Emma Huysmans en Barend Toerien. Eietydse (dikwels, maar nie altyd nie apokaliptiese) sienings van post-apartheid-Suid-Afrika kom voor in uiteenlopende tekste van Hennie Aucamp (Gekaapte tyd), Johann de Lange (Tweede natuur), André P. Brink (Donkermaan) en P.J. Haasbroek (Oemkontoe vir die nasie).

In die voorstadromans staan plaas en stad teenoor mekaar en word getrag om die hede deurgaans deur die verlede te verklaar. Diasporaliteratuur stel die nuwe land teenoor die oue en fokus dikwels juis op die verskille en ooreenkomste, afhangende van die nostalgiese geaardheid van die teks. Die sin in die hede word dikwels gevind deur 'n verbandbrenging met die verlede en tipiese aspekte daarvan, soos die agrariese. In die apokaliptiese tekste word die hede teen die verlede gestel (derhalwe ook die huidige landsituasie teenoor die oue); soms as ideaal; soms juis as negatiewe teenpool. Ook hier figureer die landelike, veral die plaas, dikwels as simboliese ruimte.

In die res van hierdie oorsig word gefokus op een verteenwoordigende roman uit elkeen van die onderskeie subgenres: Triomf (Marlene van Niekerk) as voorstadroman; Ek stamel ek sterwe (Eben Venter) as voorbeeld van diaspora-literatuur en Disgrace deur J.M. Coetzee, as tekenend van apokaliptiese literatuur. Ek maak nie daarop aanspraak dat daar van bewustelike intertekstualiteit sprake is wanneer ek hierdie romans met Laat vrugte en ander Van den Heever-tekste in verband bring nie; wél dat hulle elkeen eggo's opvang van tradisionale plaas- 
romans in die wyse waarop bepaalde tipiese gebeure, motiewe, karakters, situasies en idees in hierdie romans beslag kry.

\section{Triomf as voorstadroman}

Triomf (1990) deur Marlene van Niekerk het bykans al kultusstatus in die Afrikaanse letterkunde verkry. Die Engelse vertaling is geproblematiseer weens die tipiese Suid-Afrikanismes wat veroorsaak het dat daar uiteindelik twee verskillende vertalings gemaak is: een vir die plaaslike en een vir die internasionale mark. Die Nederlandse vertaling, weer, is aangepak deur twee bekende vertalers en die vertalings het orals die lys van topverkopers gehaal. In resensies en besprekings is hierdie roman in verband gebring met Jochem van Bruggen se Ampie en Louis Paul Boon se werk (Van Coller, 1995), met die filosofie, die godsdiens, maar ook met die geskiedenis en kultuur van die Afrikaner (Gräbe, 1996:56). Tog beweer sowel Gräbe (1996) as Van Vuuren (1999:720) dat die roman veral gelees moet word as 'n uitdrukking van universele waardes. 6

Na my gevoel (Van Coller, 1995) gaan die roman (veral) oor die lotgevalle van die Afrikaner en beskrywe dit eintlik die wyse waarop die voorstadafrikaner die politieke oorgang ná 1990 belewe. Die skokkende, sentrale geskiedenis van bloedskande is in wese metafoor van die Afrikaner se apartheidsgeskiedenis: die "saamstaan" tot die absurde toe lei tot afsondering, inteelt en bloedskandelike uitwasse en verval. Maar die roman gaan verder deurdat dit die voorstadafrikaners inbed in 'n hele kulturele geskiedenis van "plattelandse verarming en plaasverlating", gevolglike verstedeliking sonder genoeg inkomste, verdere verarming en die gevolglike sosio-kulturele gevolge, ghettovorming en oplaas 'n periferale bestaan aan die rand van 'n stad, maar steeds met geromantiseerde herinneringe aan die plaas.

In die loop van die roman word die Benades beskrywe as misplaastes in die vyandelike stedelike omgewing en die negatiewe uitbeelding van die stad herinner onwillekeurig aan die tipiese sienings van Van den Heever (o.a. Somer en Groei), Malherbe (in Die meulenaar) en selfs Boerneef in sy Boplaas-stories. Die Wes-Transvaalse plaas, Klipfontein ('n naam wat reeds nie veel goeds voorspel nie), is aanwesig in hul herinnerings (veral dié van Treppie) en oorgelewerde stories en verkry bykans mitiese

6 In my bespreking van Triomf, maak ek dankbaar gebruik van ' $\mathrm{n}$ werkstuk "Triomf van Marlene van Niekerk binne die Afrikaanse plaasromantradisie" deur Jaco Jacobs (2002), as werkstuk ingedien in my magisterprosakursus oor die Afrikaanse plaasroman. 
allure. Tog was dit 'n plek waar hul nie kon oorleef nie en wat hulle moes verlaat op soek na rykdom wat "Hertzog se spoorwegplan vir die verarmde wit man" ingehou het (p. 113). Twee van die Benade-kinders gaan bly by hul oupa en ouma op 'n ander plaas (p. 113). 'n gegewe wat net so gegryp kon wees uit die Carnegie-verslag met verwysing na bywoners en die trek na Gomorra. Die stedelike lotgevalle van die karakters in Triomf is soos die Afrikaans romanskrywers, veral Van den Heever in Groei voorspel het: hulle verloor hul hiërargiese posisie, word soos "rou kaffers" gedip (p. 114) en bly in haglike omstandighede in die losieshuis en later in 'n semi. Oumol se woorde oor die situasie op Klipfontein (p. 114) wat volgens haar darem veel beter as hul huidige omstandighede is, klink bykans soos dié van Van den Heever self. Die terugkeer vind egter nooit plaas nie en Oupop pleeg selfmoord in 'n treintrok sodat sy lyk in 'n oop trok deur die Karoo kan ry. Jacobs (2002: 8) merk op dat 'n mens dit maklik kan lees as die onttroonde patriarg se finale poging om terug te keer na die platteland.

Daar is reeds gesê dat Van Niekerk die Afrikaner as misplaastes in die stad beskrywe en ook wys op die nostalgiese verlange na die plaas. Dit beteken egter nie dat sy soos Van den Heever dieselfde ideologiese vertrekpunt deel nie. Herinneringe aan die agrariese verlede word in die loop van die roman as deel van die "muurpapier" gesien, dit waarmee die lelike bedek en verfraai word. Over geset synde, die muurpapier is 'n metafoor vir die wyse waarop die Afrikaner-verlede op private, maar ook op kollektiewe vlak gemanipuleer is en op geromantiseerde wyse ideologies herskrywe is as iets fraais.

Die Benades is bloedskandelik geïsoleer en funksioneer as 'n geslote sisteem nes die yskaste (Van Coller, 1995:273). Hulle word sodoende tekenend van die Afrikaner wat nooit by die stad kon aanpas nie ${ }^{7}$ en eintlik net 'n ryk stuk kulturele lewe (in Sophiatown) verwoes het sonder om iets in die plek daarvan te skep (in Triomf groei niks nie). Gekonfronteer met 'n nuwe politieke bestel wil hulle hul diaspora voortsit en Noorde toe trek. 8 Eers wanneer hulle besluit om te bly én hul verantwoordelkhede te aanvaar, sonder om vas te bly aan die verlede, verander hul lewensomstandighede positief (kyk ook Van Coller, 1995).

7 Jacobs (2002:10) wys in hierdie verband na ' $n$ swerm bye (p. 120), ' $n$ uil (p. 151), "goggas" en termiete, 'n bobbejaanspinnekop, hase, uile en 'n bokkie (p. 262) wat almal skynbaar wel kon aanpas by die stadsruimte.

8 Van Vuuren (1999:717) praat van die "Groot trek" as 'n geïnternaliseerde metafoor in hierdie roman. 
Van Niekerk maak in die loop van die roman korte mette met verskeie kenmerke van die tradisionele plaasroman, veral die patriargale tradisie. Mol is ' $n$ veel sterker karakter as die mansfigure. In werklikheid is sy 'n interessante vermenging van Van den Heever se tipiese vrouekarakter; sy is sterk soos die pioniersvrou, tant Willa, en bestuur oplaas ook haar eie motor.9 Tog is sy ook die "dienende Marta" (á la tant Betta) wat die hele gesin bymekaarhou. Ironies bestaan haar diens daaruit om haar liggaam ter beskikking te stel van al die mans in haar gesin, waaruit die pervertering van die tradisionele vrouefiguur uit die tradisionele plaasroman duidelik blyk.

Treppie het geen erfgenaam nie, terwyl Lambertus, die tradisionele erfopvolger, gebore is uit 'n bloedskandelike verhouding, en boonop geestelik minderwaardig is. Die patriarg, Oupop, word deur die erfgenaam vermoor as "slagoffer van die geskiedenis", omdat sy dood veroorsaak word deur die laai wat die bergplek van al die historiese relikwieë is. Boonop word naamgewing tot die absurde gevoer sodat selfs die motor en honde familiename kry. Die finale dekonstruering van tipiese eienskappe van die plaasroman vind plaas deur die vertelsituasie. In die ouer plaasromans word meestal 'n ouktoriële verteller aangetref wat 'n bepaalde ideologie onderskrywe (Van Coller, 1987:21). In Triomf, daarteenoor, is daar sprake van 'n personale vertelsituasie wat vanselfsprekend 'n vaste, onveranderbare realiteit én ideologie ondermyn. Jacobs (2002:17) merk tereg op dat die vier stemme dikwels korrektiewe op mekaar is, en dat Treppie die "muurpapier" van die ander drie se sienswyses ontmasker.

\section{Ek stamel ek sterwe: tussen parodie en nostalgie}

In Van Colller (1995a en 1995b) is daar reeds 'n saak uitgemaak dat die Afrikaanse romans van die negentigerjare dikwels in hul weergawe van die verlede huiwer tussen parodie en nostalgie. Ek stamel ek sterwe sou dalk eerder getipeer kon word as belydenis- of as biegroman in die vorm van 'n vertelling wat bykans as "binnepraat" getipeer kan word. Oënskynlik staan dit ver van die tradisionele plaasroman, wat vertelwyse, vertelafstand en storie betref. Wat sentraal staan, is Konstant Wasser-

9 Jacobs (2002:14) sê dat Mol een van die enigste karakters is wat iets probeer doen aan die Benades se situasie. Die suggestie is dat dit uiteindelik die Afrikaanse vrou sal wees vir wie dit moontlik sal wees om die eise van verandering die hoof te bied. Dit herinner onwillekeurig aan Etienne van Heerden se idealistiese slot in Die stoetmeester waardeur gesuggereer word dat politieke versoening uiteindelik slegs deur swart en blanke vroue sal kan geskied. 
man se "uitvlug" uit sy benepe boeregemeenskap, sy land, weg van tradisionele opvattings, óók wat seksuele moraal betref.

Die narratief trek 'n boog: dit begin met Konstant se ontluisterende ervaring in sy plattelandse dorp en die geïmpliseerde verwyte oor sy homoseksualiteit. Omdat hy onvergenoegd voel, besluit hy om te emigreer na Australië. Eers volg 'n kort tussenbestaan in die stad wat hier die halfwegstasie is. In Johannesburg skud hy die konserwatiewe plaaslewe van hom af en begin met 'n nuwe vrye en sinnelike lewe. Sy eerste gids is Deloris, die bruin vrou (kyk p. 21 bo), dan volg die ontmoeting met Jude, die androgene persoon,10 die verdieping van hul (vrye) verhouding, die trek na Sydney, Australië, die ontmoeting met Shane Jackson en die werk in haar vegetariese restourant, die begintekens van vigs, toenemende terugverlang na Suid-Afrika en die plaas, versoening met die vader, die slotherinnering van die oupa wie se naam hy dra, en die sterwe. So word wel nie fisies nie, maar geestelik teruggekeer na die plaas. Hierdie boog word ook versigbaar in die taalmotief. Eers is daar die aflê van die moedertaal en die gretige verstaan van elke nuanse van die nuwe taal; later word teruggekeer na die moedertaal waarvan byna elke register bespeel word. Waar die eksistensiële nood en buitestanderskap vroeër op die spits gedryf is, is dit treffend dat geëindig word met die geïmpliseerde eenwording met sy oupa (dus tradisie), dat suiwerheid volg ("suiwer wit") en dat die slotwoorde, herinner aan die tipiese "modewoord(e)" van die eksistensialisme, "ek (is)".

Die openingswoorde van hierdie roman is "Om pad te gee uit die kontrei en my in die vreemde te gaan klaarmaak vir my lewe" (p. 1).11 Dit is 'n vooruitwysing na Konstant Wasserman se emigrasie, maar ook op ironiese wyse 'n proleps na sy uiteindelike klaarmaak vir die dood (kyk ook p. 184). Konstant 12 verset hom teen die benouende kleinburgerlike gemeenskappie met hul vooroordele, maar verlaat ook die land as protes teen 'n patriargale gemeenskap en 'n politieke bestel. Weens die swak verhouding met sy vader wat hom nie as mens erken nie (p. 59), is sy

10 Uit verwysings na die "army" (p. 34), die stelling "tiete (homoseksuele) is nie tussen hul welkom nie" (p.36), "die bed army style reggemaak" (p. 45) en "die pragtige, uitgeswelde aanhangsels" (p. 121) is dit duidelik dat Jude " $n$ man is.

11 In die behandeling van hierdie roman maak ek dankbaar gebruik van Petro du Preez se werkstuk "Ek stamel ek sterwe as vernuwing van die tradisionele plaasroman" (2002) ingelewer in my magisterkursus oor die Afrikaanse plaasroman naam, tradisie en selfs die plaas nie. 
verhoudings met mans "disfunksioneel" (p. 141) en selfs nie die "army" het van hom 'n "man" gemaak nie (p. 14). Daar is in hierdie roman van die treffendste stukke oor die wroeging van 'n homoseksuele kind: "Hoekom het jy my gedrop toe ek myself in die hand begin neem het, toe jy merk ek hunker hotkant toe ...?" (p. 182). Algaande word pa se bulletjie (p. 181) 'n uitgeworpene. Die homoseksuele verhouding van Konstant, wat die stamnaam dra, impliseer verder dat erfopvolging by voorbaat uitgesluit is. Op p. 183 sê hy: "By my breek die takkie van die stamboom af." En tog bly die band onlosmaaklik: "My skedel lyk nes $\mathrm{Pa}$ s'n. Dis dan wat ek afgee vir Pa om van my te erwe" (p. 215). Hier is nog 'n omkering van die tradisionele plaasroman: op ironies wyse erf die patriarg nou van die kind!

Deur talle verwysings word ingespeel op die tipiese plaasromankenmerke. Hier word byvoorbeeld aanvanklik 'n tipiese plaasgemeenskap geteken (kyk die onderonsie met tant Trynie in die Rooistoor). Uit analepse kan die leser aflei dat Konstant hom nooit kon vereenselwig met die tipiese verwagtinge wat gekoester is ten aansien van 'n plaasseun nie (onder andere om 'n bok te skiet, $p$. 183). Waar die tipiese plaasaktiwiteite groot aandag kry in die tradisionele plaasroman, word dit hier verswyg en daarteenoor word juis die aktiwiteite in die stede noukeurig vertel; dit is asof die plaas aanvanklik enkel ideologiese ruimte is. ${ }^{13}$ Later (kyk byvoorbeeld p. 214) word die plaasruimte besonder liries beskrywe.

Die kontras plaas/stad in die roman word hier op die spits gedryf en die stad verteenwoordig baie van die negatiewe eienskappe (dranksug, goddeloosheid en morele en sedelike verval) soos dit voorkom in Van den Heever se Droogte en Groei. Venter gee met Foxtrot van die vleiseters 'n duidelike parodiërende blik op die tipiese Afrikaanse plaas. In Ek stamel, ek sterwe is die stadsruimte vir Konstant kennelik 'n ontsnappingsruimte, weg van die benouende plaasbestaan. Tog word die stadslewe (veral in die lig van die latere lyding van die hoofkarakter) geen utopie nie. Hierdie roman sou amper gelees kon word as 'n voortsetting van Van den Heever se herhaalde waarskuwings teen die stadsbestaan!

Maar die dekonstruksie van die tipiese kenmerke van die plaasroman gaan verder. Konstant laat hom besonder neerhalend uit oor die

13 Dit is belangrik dat so gefokus word op kos, een van die tipiese elemente van plaaslewe. Heel veelseggend word hier egter vertel van die voorbereiding van vegetariese disse as duidelike (ideologiese) teenpool van die plaasbestaan waar vleis sentraal is. Hierdie kontras speel ook ' $n$ belangrike rol in die vorige Venter-roman, Foxtrot van die vleiseters. 
tradisionele godsdiens (p. 48-52). 'n Treffende episode is die besoek van Konstant se vader, Raster, en ds. Pietie aan Konstant in die stad. Op treffende wyse word dit 'n parodie van die tipiese plattelandse huisbesoek. Die skaapvleis word voorberei en die huis skoongemaak, resepte word bespreek, na welstand verneem en "veel gesê oor boggerol". Konstant raak toenemend los van die kerk (kyk p. 99) en neig eerder na die Boeddhisme met sy vegetariese en meditatiewe leefwyse (kyk p. 101 en p. 163), gaan soek later hulp by 'n "osoonsangoma”, Gordana.

In die tipiese plaasroman is die opset chronologies en word ouktorieel vertel. Wat karakterisering betref, oorheers die sogenaamde "direkte definisie" (kyk die openingsparagrawe van Laat vrugte). Hier word veel meer gebruik gemaak van indirekte karakterisering en omdat daar vertel word uit 'n ek-perspektief, word die leser mede-ervaarder van sy pyn en wroeging. Hier is geen sprake van prosestyd nie; veel eerder retrospektiewe tyd (omdat terugskouend vertel word), maar dan ook keertyd omdat die onontsnapbare dood van Konstant afwagting en spanning skep by die leser.

Ek stamel ek sterwe verskil van ander moderne Afrikaanse plaasromans met hul duidelike parodiërende instelling; hul ondergrawing van al die waardes van die tradisionele plaasroman. Tipies van die diasporaliteratuur neem nostalgiese elemente 'n belangrike rol in. Ten spyte van politieke en ideologiese verskille, bly die "linear consciousness" (Coetzee) onverswak.

\section{Disgrace gelees teen die agtergrond van die Afrikaanse plaasroman ${ }^{14}$}

J.M. Coetzee het gesaghebbend geskryf oor die Afrikaanse plaasroman in sy werk White writing. On the culture of letters in South Africa (Coetzee, 1988). In sy outobiografiese werk Boyhood (Coetzee, 1998) skets hy sy jeugjare met 'n sekere verskeurdheid tussen Afrikaans en Engels. Hy droom daarvan om oom Son se seun te wees en om sy lewe deur te bring op 'n plaas, selfs al sou dit beteken dat hy dan sal moet kies om Afrikaans te word (Boersema, 2002:1). Soos reeds eerder opgemerk, sien Coetzee die plaas as 'n belangrike mitiese en ideologiese ruimte in die bewussyn van die Afrikaner en sou 'n mens bykans kon sê, in die Suid-Afrikaanse kollektiewe onbewuste.

14 Vir hierdie gedeelte maak ek dankbaar gebruik van insigte uit ' $n$ werkstuk "Disgrace in die tradisie van die Afrikaanse plaasroman" deur Dick Boersema. Hierdie werkstuk is ingelewer tydens my magisterkursus oor die Afrikaanse plaasroman in 2002. 
Wanneer die werke van C.M. van den Heever as 'n geheel bekyk word, blyk dat die plaas vir die Afrikaner 'n skuilplek is teen die magte daarbuite. Hierdie bedreiginge is soms gekonkretiseer in die figure van spekulante en geldskieters; soms is die stryd teen kosmiese magte soos hael en veral droogte, maar daar is altyd ook die stad en dit wat daardeur verteenwoordig word: sedelike verval, armoede, oneerlikheid en volksvreemdheid. Soos gesê, pleit Van den Heever vir 'n terugkeer na die plaas, sonder om werklik antwoorde te verskaf oor hoe oorleef moet word (bv. in Groei). Dit is nie slegs 'n onrealistiese idealisme wat hier na vore kom nie; 'n sentrale opvatting van die romantiek is die vryheidsdrang. Van den Heever skyn te impliseer dat dit beter is om onder te gaan op jou eie stuk grond, met jou trots en onafhanklikheid intakt, eerder as om hulpbehoewende en verknegte in die stad te wees.

In Disgrace is die hoofpersoon, David Lurie, 'n siniese akademikus wat op egoïstiese wyse sy eie plesier vooropstel, afstand bewaar van mense en aanvanklik opgesaal is met hubris (kyk die ooreenkoms tussen hom en die gevalle engel, Lucifer). Ná 'n klag van seksuele teistering teen hom ingebring is, weier hy om verskoning te vra en wyk uit na Salem waar sy dogter, Lucy, op 'n kleinhoewe leef. Hy kom onder die indruk van haar verbintenis met die tipiese Afrikanerpioniersvroue en van haar vermoë om op 'n eenvoudige, maar onafhanklike wyse 'n lewe vir haarself te maak. Hier wil Lurie hom terugtrek en verder werk aan sy opera oor die romantiese digter, Byron. Hieruit blyk reeds hoe Coetzee die tradisionele plaasroman parodieer: nie die kind vertrek na die stad nie, maar die vader na die plaas; nie die stad is die gevaarlike ruimte nie, maar veel eerder die plaas; van die plaas as ruimte van beskutting bly niks oor nie. Algaande in die roman word ook 'n pennestreep getrek deur ander sentrale aspekte van die tradisionele plaasroman: patriargale waardes, die wyse waarop die ruimte uitgebeeld word (veral die hiërargiese aspek daarvan), die aanspraak deur die plaas op die land, die tradisionele uitbeelding van die vrou, ensovoorts.

Een van die mees sentrale aspekte van die tradisionele plaasroman is dié van erfopvolging en die primaat van die patriargale. In Disgrace is Lurie self nie die besitter van die plasie nie, maar sy dogter. Hy probeer deurgaans optree as gids vir vroue (soos vir die enigsins onwillige Melanie Isaacs). Gou besef hy dat sy dogter hom nie as gids wil aanvaar nie: "She says I am not a good guide" (p. 162). Oplaas word sy gidsrol nog verder gedekonstrueer as hy slegs mag optree as gids van die siele van die ontslape honde.

Reeds in die openingsparagrawe van Laat vrugte word die geslagte teenoor mekaar gestel en word die gesag van die patriarg uitgedaag. In die slot keer Henning egter terug met klein Sybrand op sy arm waardeur 
gesuggereer word dat die patriargie intakt bly. In Disgrace geskied die afrekening met die (let wel tradisionele blanke) patriargie finaal. Nie net word die "erfopvolger" nou 'n kind van gemengde herkoms nie; boonop is dié kind verwek deur verkragting, deur 'n swarte wat boonop vertraag is. Hierdie ideologiese ommekeer gaan 'n hele stuk verder as Brink in Houd-den-Bek waar die gekleurde erfopvolger darem in liefde verwek word. Boonop keer Lucy haar teen haar vader (en sy stel opvattings) deur te weier om die kind te aborteer, haar gewillig te onderwerp aan Petrus en as "sy vrou" bereid is om haar onderhorigheid aan die wêreld te toon. Haar finale kniebuiging is as sy besluit om voort te gaan as sy "bywoner". Tereg sien Boersema (2002:8) hierdie ondermyning as bykans oordrewe.

In die tradisionele plaasroman is daar bepaalde "koloniale" magsverhoudinge aanwesig: die eienaar het die land "makgemaak en tot "plek" verander en op tasbare wyse sy merke op hierdie ruimte geplaas, byvoorbeeld deur die aanlê van 'n bos, 'n element wat in byna elke tradisionele plaasroman voorkom. ${ }^{15} \mathrm{Op}$ die plaas is hy die baas en al die ander (sy vrou, kinders, bywoners, knegte en arbeiders) neem hiërargies 'n ondergeskikte plek in. In Disgrace word die hiërargie omgekeer: Petrus wat aanvanklik arbeider was, ontwikkel tot bywoner, buurman en later die effektiewe eienaar van die kleinhoewe. Die ommekeer geskied in terme van postkoloniale magsverhoudings waar die vroeëre magshebbers van alles gestroop word.

In die tradisionele plaasroman word die siening gehuldig dat die oorspronklike eienaars van die plaas hul eiendomsreg verwerf het deur hul pioniersarbeid "those deserve to inherit the earth who make best use of it" (Coetzee, 1988:3). Die nageslag moet telkens as 't ware die grond verdien deur te boer soos hul voorouers, met kundigheid, liefde en deur te vergroei met die plaas en die voorgeslag. Boersema (2002:7) haal Coetzee aan wat sê dat hy nie bewus is dat die tradisionele plaasroman ooit vra "whether it is possible to establish natural right over a farm against his will (as, for examplem in enforced settlement of a debt) from a disposessed 'natural' owner". Hierdie vraag staan volgens hom sentraal in Disgrace. Eers is dit Lucy wat 'n plaas bekom waarvan die oorspronklike bewoners lank reeds stad toe geskuif het. Later word Petrus effektief die nuwe eienaar en is hy inderdaad "foreward-looking"

15 Die naam van die plaas in Laat vrugte is nie verniet "Boskloof" nie. Oom Sybrand se oupa het reeds die populiere geplant wat steeds met die seisoene verander van kleur. 
(p. 136), 'n vertaling van "vooruitboer" wat Coetzee16 (1988) gebruik (Boersema, 2002:7). Só kom 'n totale ommekeer tot stand, ook wat die erfopvolging betref: "So it will go on, a line of existences in which his share, his gift, will grow inexorably less and less, till it may as well be forgotten" (p. 217).

Terwyl 'n oorkoepelende interpretasie van Disgrace 'n mens steeds ontwyk, wil dit lyk asof die roman iets wil sê oor prysgawe: van jou onafhanklikheid, jou voorregte, jou identiteit. Prysgawe van die plaas, daardie stukkie onvervreembare grondgebied, is hiervan net ' $n$ geringe onderdeel. Anders as by Van den Heever is daar geen plek meer waar die blanke homself kan verskans en sy mag kan behou nie.

Lucy is aanvanklik duidelik verwant aan die tradisionele pioniersvrou wat onafhanklik boer en haar nie van haar plasie wil laat verdryf nie. Tog is sy bereid om haar verkragting te sien as die betaling (van skuld) aan die nuwe maghebbers en as wyse om haar verblyfsvergunning te verdien. Oplaas leef sy as lesbiër voort in onderdanigheid aan haar nuwe "man". In 'n sin word die ou patriargie daardeur weer herskep en bykans gesuggereer dat ook vroue onderhorig sal bly binne die nuwe bedeling. Ten minste was C.M. van den Heever duideliker aan die kant van die onderdrukte vroue wat hy beskrywe het (kyk ook Van Coller, 1987:30).

Uit die voorafgaande is dit hopelik duidelik dat Van den Heever se werk bly meespreek in eietydse Suid-Afrikaanse literatuur, nie net as konnotatiewe verwysings nie, maar inderdaad deur intertekstuele terugwysing. Enige vorm van intertekstualiteit (selfs deur die parodie) is altyd 'n huldebetuiging aan die bronteks. Dat dit gebeur deur sommige van ons grootste skrywers is genoeg rede om Van den Heever opnuut veilig te verskans in die kanon.

\section{Bibliografie}

Antonissen, Rob. s.d. Die Afrikaanse letterkunde van aanvang tot hede. Tweede druk. Johannesburg/Kaapstad/Bloemfontein : Xlason.

Botha, Elize. 1983. Verskyningsvorme van die romantiek in die Afrikaanse prosa: D.F. Malherbe en daarna. D.F. Malherbe-gedenklesing no 2. Bloemfontein : Universiteit van die Oranje-Vrystaat.

Boersema, Dick. 2002. Disgrace as moderne plaasroman. Ongepubliseerde honneurswerkstuk. Bloemfontein : Universiteit van die Vrystaat.

Coetzee, Ampie. 2000. 'n Hele os vir 'n ou broodmes. Grond en die plaasnarratief sedert 1595. Pretoria/Kaapstad : Van Schaik/Human \& Rousseau.

16 In die ommekeer van hiëragiese verhoudings sal ook gewys kon word op die verhouding mens-dier op die tradisionele plaas wat in hierdie roman omgekeer word "This is the only life there is. Which we share with animals" (p. 74). 
Coetzee, J.M. 1988. White writing. On the culture of letters in South Africa. New Haven/London : Yale University Press.

Coetzee, J.M. 1998. Boyhood, scenes from a provincial life. London : Reprint.

Coetzee, J.M. 2000. Disgrace. London : Vintage.

Dekker, G. 1959. Resensie: Groei, Die Huisgenoot, 29 Desember 1933. In: Nienaber, P.J. (red.) Gedenkboek C.M. van den Heever 1902-1957. Johannesburg : Afrikaanse Pers-Boekhandel. p. 183-188.

Du Buson, M.S. 1959. Ons grootste metafisiese digter. Gedenkboek C.M. van den Heever 1902-1957. Johannesburg : Afrikaanse Pers-Boekhandel. p. 101-110.

Du Preez, Petru. 2002. Ek stamel, ek sterwe se verwantskap met die moderne Afrikaanse plaasroman. Ongepubliseerde honneurswerkstuk. Bloemfontein : Universiteit van die Vrystaat.

Du Plooy, Heilna. 1999. Profiel van C.M. van den Heever. In: Van Coller, H.P. (red.) Perspektief en profiel (II). Pretoria : Van Schaik. p. 653-664.

Gräbe, Ina. 1996. Brutalization of cultural and universal values in Marlene van Niekerk's Triomf: relativity of cultural relativism or redefinition of universal validity? In: Hendrix et al. (eds.) The search for a new alphabet. Literary studies in a changing world. Amsterdam : John Benjamins. p. 105-110.

Grosskopf, J.F.W. 1932. Plattelandsverarming en plaasverlating. Deel I van Die armblanke-vraagstuk in Suid-Afrika. Verslag van die Carnegie-kommissie. Deel I. Stellenbosch : Pro Ecclesia.

Grové, A.P. 1951. Jochem van Bruggen die realis. Standpunte, 1(6):2-10. Herdruk in Grové, A.P. 1958. Oordeel en vooroordeel. Kaapstad : Nasionale Boekhandel.

Haarhoff, T.J. 1959. Gedagtes oor C.M. van den Heever en sy werk. In: Nienaber, P.J. (red.) Gedenkboek C.M. van den Heever 1902-1957. Johannesburg : Afrikaanse Pers-Boekhandel. p. 23-42.

Jacobs, Jaco. 2002. Triomf se verwantskap met die moderne Afrikaanse plaasroman. Ongepubliseerde honneurswerkstuk. Bloemfontein : Universiteit van die Vrystaat.

Kannemeyer, J.C. 1978. Geskiedenis van die Afrikaanse literatuur (I). Kaapstad/ Pretoria : Academica.

Koch, Jerzy. 2002. Outsider onder de zijnen. Vormen van xenofanie in de Afrikaanse roman. Wroclav : Universiteit van Wroclav. Ongepubliseerde habilitasie-proefskrif. Gepubliseer 2002. Wroclaw : Wydawnictwo Uniwersytetu Wroclawskiego.

Malherbe, D.F. 1959. lets oor C.M. van den Heever en sy werk. Tydskrif vir Letterkunde September. In: Nienaber, P.J. (red.) Gedenkboek C.M. van den Heever 1902-1957. Johannesburg : Afrikaanse Pers-Boekhandel. p. 13-18.

Perreira, E. 1992. Romantiek. In: Cloete, T.T. (red.) Literêre terme en teorieë. Pretoria : HAUM-Literêr. p. 447-452.

Pienaar, P. de V. 1959. Resensie: Groei, Die Vaderland, 27 Oktober 1933 In: Nienaber, P.J. (red.) Gedenkboek C.M. van den Heever 1902-1957. Johannesburg : Afrikaanse Pers-Boekhandel. p. 178-182.

Schoonees, P.C. 1959. C.M. van den Heever as prosakunstenaar. In: Nienaber, P.J. (red.) Gedenkboek C.M. van den Heever 1902-1957. Johannesburg : Afrikaanse Pers-Boekhandel. p. 84-96.

Solz, Maura. 1959. My vader soos ek hom geken het. In: Nienaber, P.J. (red.) Gedenkboek C.M. van den Heever 1902-1957. Johannesburg : Afrikaanse Pers-Boekhandel. p. 43-49.

Van Coller, H.P. 1987. Laat vrugte behandel deur prof. H.P. van Coller. ReuseBlokboeke. Pretoria/Kaapstad : Academica. 
Van Coller, H.P. 1995. Die Afrikaanse plaasroman as ideologiese refleksie van die politieke en sosiale werklikheid in Suid-Afrika. Stilet, VII(2):22-31.

Van Coller, H.P. 1995a. Tussen nostalgie en parodie: die Afrikaanse prosa in die jare negentig. Deel I. Tydskrif vir Geesteswetenskappe, 35(3):197-208, September.

Van Coller, H.P. 1995b. Tussen nostalgie en parodie: die Afrikaanse prosa in die jare negentig. Deel II. Tydskrif vir Geesteswetenskappe, 35(4):271-279, Desember.

Van Gorp, H., Ghesquiere, R. \& Delabastita, D. 1998. Lexicon van literaire termen. Groningen, Deurne : Nijhoff/Plantyn.

Van Heerden, Ernst. 1982. Profiel van C.M. van den Heever. In: Nienaber, P.J. (red.) Perspektief en profiel. Johannesburg : Perskor. p. 335-340.

Van Heerden, W. 1959. Die denker. In: Nienaber, P.J. (red.) Gedenkboek C.M. van den Heever 1902-1957. Johannesburg : Afrikaanse Pers-Boekhandel.

Van Niekerk, Marlene. 1990. Triomf. Kaapstad : Queillerie.

Van Vuuren, Helize. 1999. Profiel: Marlene van Niekerk. In: Van Coller, H.P. (red.) Perspektief en profiel. Pretoria : Van Schaik. p. 709-721.

Venter, Eben. 1996. Ek stamel ek sterwe. Kaapstad : Queillerie.

\section{Kernbegrippe:}

betrokke literatuur

Coetzee, J.M. Disgrace

herlesing van klassieke tekste

intertekstualiteit

moderne plaasroman

Van Niekerk, M. Triomf

\section{Key concepts:}

Coetzee, J.M. Disgrace

intertextuality

littérature engagée

modern farm novel

rereading of classical texts

Van Niekerk, M. Triomf 